\title{
Forum
}

\section{Goethe, His Era, and Islam}

\author{
Enes Karić
}

Goethe, the complete artist, is our antipode: an example for others. Alien to incompletion, that modern concept of perfection, he refused comprehension of others' dangers; as for his own, he assimilated them so well that he never suffered from them. His brilliant destiny discourages us; after having sifted him in vain in an attempt to discover sublime or sordid secrets, we give ourselves up to Rilke's phrase: 'I have no organ for Goethe. ${ }^{1}$

Goethe constructed his spiritual world with an unrivalled openness to the natural cycle of creation and destruction, the cultural accomplishments of different eras and places, the wisdom stretching beyond the whirlwinds of history. Being an 'explosive liberator' of all living forms of nature and culture, Goethe found the Enlightenment's idea of history as a self-contained, linear advancement of the human mind to be a constricting notion, one that downplayed the role of humans in God's work and presented an unacceptable erasure of interpersonal relationships and reality. ${ }^{2}$

Enes Karić is a professor of Qur'anic studies and history of the interpretation of the Qur'an at the Faculty of Islamic Studies, University of Sarajevo. He previously served as the Minister of Education, Science, Culture, and Sports with the Republic of Bosnia and Herzegovina (1994-1996).

I would like to thank Dževad Karahasan, Salim A. Hadžić, and Nusret Čančar for reading an earlier draft of this essay. Their suggestions helped me temper some parts of it. 
Many years have passed since two Germans, Annemarie Schimmel (19222003) and Katharina Mommsen (b. 1925), attracted significant scholarly and critical attention with their studies of Islam. Their treatment of the multifarious worlds of Islam or, to be more precise, the many universes of Islam and their representation/presence in science, culture, and civilization, is a good example of authentic and careful consideration of Islam in the Western world of the twentieth century. While the work of Annemarie Schimmel is extensive, with her being dubbed the 'diva of Oriental studies'3 due to her wide-ranging investigation of the depths of Islam (from the point of view of both geography and civilization), the scholarly work and impact of Katharina Mommsen is characterized by an astonishing thoroughness, an astute, extremely detailed documentation of the various facets of Islam. We should also note Sigrid Hunke (1913-1999), whose book Allah's Sun Over the Occident also attracted much attention.

In 2008, the first complete translation of Katharina Mommsen's book Goethe and Islam appeared in Bosnia and Herzegovina, expertly rendered into the local language by the Germanist Vedad Smailagić. ${ }^{4}$ The brilliant translating debut suggested Smailagić was poised to follow in the footsteps of another Banja Luka native, Nerkez Smailagić (1927-1985), ${ }^{5}$ whose translating feats over three decades ago became a source of pride for us all. Dževad Karahasan had come across the book Goethe und der Islam and persuaded his friends that Mommsen's work needed to be translated, not just for our sake but also for a broader audience, as there were few Bosnian, Croatian and Serbian intellectuals and writers aware of the influence of Islam on Goethe's work and thought, his Islamic imagery, his drawing upon Islamic scholars and spiritual leaders, the Poet's flights of imagination inspired by the symbols of Islam.

\section{The Entrancement with Goethe among Bosnian Muslims}

In Muslim circles in Bosnia the interest in Goethe's relationship with Islam was twofold: both scientific, ruled by the mind, as well as emotional, ruled by the heart. Two important facts help explain this enchantment with Goethe. The first is local. Goethe, in his unique way, universalized the Bosnian ballad Hasanaginica in 1775 by translating it (most likely from Italian) into German. According to Alija Isaković (1932-1997), Goethe published Hasanaginica twice, in 1778 (anonymously) and 1779 (under his own name). ${ }^{6}$ In addition to the writings of Alija Isaković, two other works-Smail Baličs (1920-2002) Goethes "Klagegessang Von Den Edlen Frauen Asan Agas", Eine bosnische Volksballade erobert die Welt and Camil- 
la Lucerna’s Južnoslovenska balada o Hasanaginici, njezin prijevod od Goethea-are particularly useful when trying to shed light on Goethe's interest in Hasanaginica.

The second fact which helps explain the Bosnian reception of Goethe is universal, and has to do with Goethe's broader relationship to Islam. Many of the works on Goethe's 'diwan phase' and his attitude towards Islam were borne of the realization that one of the greatest European poets respected the Islamic faith. Deeply rooted in the Western hemisphere, the poet Goethe directed the attention of Europe and the West to an Islam worthy of respect, and did so through the efforts of his mind and spirit (i.e. his own agency) in an era when the West had almost completely conquered Islamic peoples. This fact had a kind of therapeutic effect on Bosnian Muslim and Islamic intellectuals: in Goethe's appreciation of Islam we found echoes of our own attempts to valorize our faith in the challenging times that had befallen us. Bosnian writings on Goethe and his attitude towards Islam bore no traces of a critical edge, excepting a few uncharacteristic comments suggesting that the Quran sought to repress poetry, that its style was lower than the style of poetry, and that prophet Muhammad covered women's faces (more on this in the abovementioned work by Mommsen).

Forty years ago, few in Bosnia knew about Mommsen and her interest in Goethe's treatment of the Islamic East. Her text Geteov odnos prema islamu was published in 1968 in issue 7-8 of the Gazette of the Supreme Head of Office of the Islamic Community (VIS). ${ }^{7}$ The same text, in a slightly different translation (the name of the translator not given), was also published in Takvim in 1972, under the same title. ${ }^{8}$ This was clearly an abbreviated chapter from her book Goethe und der Islam.

About ten years later, in 1983, Islamska misao commemorated the $150^{\text {th }}$ anniversary of Goethe's death by publishing Fehim Bajraktarević's (18891970) "Utjecaj istoka na Getea" and Hilmo Neimarlijas "Dug Geteu". ${ }^{9}$ In his study (originally published in 1939), Bajraktarevic ${ }^{10}$ delved into the history of Goethe's interest in Islam and explored the Poet's preoccupation with Islamic topics. Bajraktarević also explored the sources that helped Goethe expand his knowledge of the Islamic East. In particular, Bajraktarević provided a wealth of information about Goethe's countrymen who spent time there, for he himself had only a single first-hand encounter with Muslims:

The poet had just one live, albeit mediated encounter with the East: when Russian forces passed through Weimar during the Napoleonic wars 
(1814), among them were several Bashkirs who prayed with their mullah (khawaja) in the auditorium of a Protestant school. ${ }^{11}$

Thus Bajraktarević understandably devoted a large part of his study to Hafez Shīrāzì (1325/6-1389/90) and his influence on the West-East Diwan (West-östlicher Divan). Bajraktarević's conclusions remain pertinent and valuable to us today.

In 1983, then, Neimarlija published the essay Dug Geteu, ${ }^{12}$ which is still considered the best such text on Goethe. The author introduced the "genius from Weimar" and his "prophetic" mission, adroitly explaining that Goethe found in Islam (or rather, in his own understanding of Islam), a confirmation of his worldview as well as his poetic and intellectual practice. ${ }^{13} \mathrm{With}$ these excellent essays, Bajraktarević and Neimarlija paved the way for an intellectually challenging conversation about Goethe.

In 1999, the Gazette of the Riyasat of the Islamic Community published the essay Goethe - musliman? written by Akbar Moghaddasa and translated from German by Salim A. Hadžić. ${ }^{14}$ In the last ten years Hadžić has published well-argued, comprehensive studies on Goethe, as well as translations of the most important parts of Goethe's opus. In this paper we draw upon some of Hadžićs's texts.

In 2000, the Gazette serialized the extensive study of Annemarie Schimmel Gete $i$ islam (Goethe and Islam), ${ }^{15}$ originally published in German as Goethe und der Islam ${ }^{16}$ and translated by Hadžić. In his note accompanying the first of the three serialized parts, Hadžić notes that 1999 marked the $250^{\text {th }}$ anniversary of the birth of the greatest German poet, who was also, according to the evidence presented in the study, a Muslim lyrical poet. $^{17}$

Authors in Bosnian Islamic journals have often spoken of Goethe in a deferential, celebratory tone, but this is a topic to be discussed on another occasion.

\section{A Monograph on One of Goethe's Many Spiritual Abodes}

Goethe und der Islam by Katharina Mommsen is a challenging work that spellbinds its readers in a number of ways:

1) She draws a spiritual portrait of Johann Wolfgang von Goethe (17491832) in those periods of his life that came to be tied with Islam (or, his version of Islam), through the flight of his poetic imagination and the workings of destiny (in which Goethe was a staunch believer). 
2) Mommsen's work is a monograph of Goethe's era, its interest in the Islamic East, and the spiritual atmosphere of the times, in which the song of Goethe's spirit and the light of his intelligence spread out from Weimar.

3) The book is a chronicle of contemporary poetic and literary treatments of the Islamic Orient in Germany, and to some extent the rest of Europe.

4) It reads as a micro-history of a European competition, inaugurated by Goethe, between 'the Message of God's Revelation' and 'the Message of Goethe the Poet'. Such competitions were common in the history of Islam, but Europe had not seen such an intense, particular expression of it prior to Goethe.

5) She writes extensively of Goethe's few unfavourable (and for traditional Muslims simply unacceptable) views on the Qur'an and Prophet Muhammad, providing a more balanced account than the unmitigated enthusiasm of the Bosnian texts mentioned earlier.

The title of Mommsen's monograph offers various interpretations. Various clichéd oppositions ('Islam and the West', 'Islam and Europe') pit a global, universal religion against a continent or a hemisphere (not least with malice, promoting a dualistic and Manichaean worldview). Despite the trend of such encompassing titles, Mommsen named her book Goethe und der Islam, choosing to focus on the encounter between Islam and a single man. She did the same with her book Goethe and the Arab World (Goethe und die arabische Welt). ${ }^{18}$ In this respect, the title Goethe und der Islam is evocative and meaningful on several levels. Although Goethe, as the book suggests, became familiar with Islam (and embarked on a dalliance with Islam that was uncharacteristic for his time) through various European translations of the Qur'an (which left him unimpressed), as well as Hammer-Purgstall's translation of diwan poetry written by the great Persian poet Hafez Shīrāzi ${ }^{19}$ that made all of Goethe's numerous works a sort of dialogue with Hafez, Mommsen did not name her book Goethe and Hafez Shìrāzi. That is, Mommsen dared the title Goethe und der Islam, even though she must have suspected that it would only provoke such questions as which Goethe (which period in his life)? Which Islam (of the Qur'an? The hadith? The Persian or Arab cultural sphere? Islam of the poets? The philosophers? The people?)? We witness Mommsen's attempts to shed light on the numerous, glorious feats of Goethe's colossal poetic, literary and intellectual undertakings, while at the same time trying to remain true to 
the title of the book and to answer a difficult question: what kind of Islam did Goethe discover? What kind of Islam revealed itself to him?

We insist on this issue, since the reaction to Goethe's work (especially on this topic) has been tinged with more than a little naiveté. Fortunately, Mommsen herself is aware of many of the blind spots in the reception of Goethe's work. For some Muslims, Goethe's genius was overpowering, entirely illuminating and stimulating (to such an extent that fatwas were even issued proclaiming Goethe to be a true Muslim in his life, his poetry, and his reasoning) $;{ }^{20}$ of course, the same could be said of the reputation the Poet from Weimar enjoyed among Christians (such as Mommsen herself) who regarded him as a true Christian and found in his work evidence of loyalty to the Christian tradition-allegedly so strong that Goethe left an invisible (immaterial, spiritual, eternal) cross in some of his verses! ${ }^{21}$

Trying to religiously appropriate Goethe and the symbolic significance of his work, however, is a pointless, Sisyphean task, especially when trying to establish Goethe's intimate religious or non-religious feelings. Such an appropriation leads to regionalizing Goethe's genius, revealing the narrow-mindedness of the parties involved in the dispute and betraying the phenomenon that was Goethe and the wonders he produced. Therefore, in what follows we will simply consider the claims and documents of Mommsen and others who have written about Goethe's spiritual quests.

\section{Goethe's Spiritual Quests}

Even in his youth, Johann Wolfgang von Goethe was keen on constructing his own, personal kind of religiosity; to quote Mommsen, "he began developing a completely personal religiosity (ganz persönliche Religiosität zu entfalten)". ${ }^{22}$ The news of the devastating earthquake in Lisbon in 1755 left a great impression on the six-year-old Goethe. The memory of the horrifying death of thousands of people would return to haunt him throughout his life, prompting Goethe to write that the earthquake revealed the "Creator and Ruler of the Heavens and Earth' to not be 'very fatherly at all' ('der Shöpfer und Erhalter Himmels und der Erden' sich 'keineswegs väterlich' bewies)." ${ }^{3}$

In his boyhood and adolescent years, Goethe tried approaching as much as possible the 'great God of nature' (dem Großen Gotte der Natur unmittelbar zu nähern suchte). ${ }^{24}$ Goethe's desire to come close to the 'great God of nature' was partly inspired by the advanced stage of the Enlightenment movement in Europe, which formed its own truth about the world, espousing the immutability of natural laws and celebrating nature as 'God's abode'. Wanting to find his own faith, the young Goethe constructed pyr- 
amid-shaped altars for his God of nature, with different natural products placed on each of the pyramid levels (er baute seinem Gott der Natur ein Altar in Pyramidenform, auf dem in verschiedenen Abstufungen Naturprodukte aufgeschichtet waren) ${ }^{25} \mathrm{~A}$ pyramid is a regular geometric shape, firmly etched in the collective human mind. Young Goethe reasoned that if we were intent on constructing temples and places of worship for God, then these structures should be built according to the inner logic of the mind, reflecting the inner workings of Nature itself.

Even though the Enlightenment attracted Goethe's insatiable curiosity, it ultimately failed to provide him with firm answers. As he aged, Goethe became increasingly preoccupied with the religion of the heart and found the external world of his era to lack "balance between the internal religion of the heart and the external religion of the church (in welchem er eine Übereinstimmung zwischen der inneren Religion des Herzens und jener äußeren der Kirche entbehrte)." ${ }^{26}$

Mommsen finds that Goethe, a member of the Protestant tradition, sought to learn more about "heretics who had been presented as infidels". Young Goethe never questioned the initial impulse of the Enlightenment (he was even enraptured by some of its trends), but plenty of evidence suggests that middle-aged Goethe disagreed with the Enlightenment concept of nature as a godless machines. This version of the Enlightenment could not provide the Poet from Weimar the spiritual nourishment he craved; as he said, "The spirit of contradiction and the inclination towards paradox are inherent to us all (Der Geist des Widerspruchs und die Lust zum Paradoxen steckt in uns allen)." ${ }^{27}$ Further evidence could be found in Goethe's belief that faith in God and faith in divine things are part of the same holy chalice (ein heiliges Gefäß). ${ }^{28}$

Nature and the respect it commanded were the cornerstones of Goethe's early philosophy and poetry. As he aged, his sensitivity to nature did not wane. On the contrary, it only grew stronger. We have neither the time nor the space here to revisit the many times Goethe set out from his birthplace of Frankfurt (on Maine) to travel through river valleys, the remote parts of Italy, Switzerland, etc. to bask in the wonders of Nature. In fact, Goethe

constructed his spiritual world (...) with an unrivalled openness to the natural cycle of creation and destruction, the cultural accomplishments of different eras and places, the wisdom stretching beyond the whirlwinds of history. Being an 'explosive liberator' of all living forms of nature and culture, Goethe found the Enlightenment's idea of history as 
a self-contained, linear advancement of the human mind to be a constricting notion, one that downplayed the role of humans in God's work and presented an unacceptable erasure of interpersonal relationships and reality. ${ }^{29}$

Goethe's relationship to Nature was different from that of his contemporary, Hegel, because "Goethe sought unity in perceived nature, while Hegel sought unity in the historical spirit. This is why Hegel insisted on the 'cunning of the mind' while Goethe believed in the cunning of nature." 30

Many Muslim scholars of Goethe's work, especially those emotionally invested in the subject matter, have ignored the fact that the poet Goethe formulated his own faith and searched within himself for his personal religion long before encountering the Qur'an. The fact that he later found confirmation in the Qur'an for many of his personal beliefs was a result of his extensive research of the world of Islam, the prophet Muhammad, and the other side of the Mediterranean (the Occident), which the West at that time had begun to discover. This faraway world of Islam appeared to Goethe as untainted nature, something magical, unknown, and charming. Annemarie Schimmel brilliantly described Goethe's epoch, the spiritual atmosphere of Goethe's times:

At the turn of the $18^{\text {th }}$ century a new facet of the Orient became visible. The collection of stories 1001 Nights appeared in French, translated by Galland who died in 1715, and those familiar with German, English and French literature, painting and music realise the immense influence of these Arabic stories on European art. It was an Orient full of fairies and ghosts, no longer the Orient of the Anti-Christ against whom wars should be waged, but rather something playful. ${ }^{31}$

Goethe's discovery of the 'rich Nature' of the Orient was also recognised by Edward Said (1935-2003), who included him alongside Byron and Hugo among those who "restructured the Orient by their art and made its colours, lights and people visible through their images, rhythms and motifs." 32

Goethe was so preoccupied with discovering authenticity in the Orient, or projecting on it an imaginary authenticity, that a chapter in his work West-östlischer Divan carried the far-reaching title Hejira. Salim A. Hadžić carried out a brilliant analysis of the poem, showing why it was chosen as the opening poem of Goethe's West-Eastern Diwan. ${ }^{33}$ The East was the place to go to, since it was there that Goethe found numerous poets writing about Nature-in fact, their poetry was the song of Nature itself. Below is 
Hadžićs translation of the famed poem, originally written in German in 1816:

\section{Hidžra}

Sjever, Zapad i Jug se razdvajaju,

Prijestolja se ruše, carstva se tresu,

Bježi daleko, i na čistom Istoku

Da okusiš patrijarhški vazduh;

Uz ljubav, piće, pjesmu

Da podmladi Hiserov izvor tebe.

Tamo ću se ja vratiti,

U čistoću i pravednost,

Ljudskom rodu da pronađem

Nit porijekla dubokoga.

Gdje su još od Boga primali

Nauku nebesku pravu,

I razbijali nisu sebi glavu.

Gdje preci visoko se poštovali,

Svaku stranu službu odbijali;

Omladini data granica:

Uže misli, nego vjera,

Kako je riječ tamo tako dragocjena bila,

Jer riječ je govorena bila.

Hoću s pastirima da se družim,

$\mathrm{U}$ oazama se rashlađujem,

Kad putujem s karavanama,

Mahramom, kahvom i mošusem da radim;

Svaku stazu hoću da kročim

Od pustinje do gradova.

Teški gorski put gore - dolje

Tješit će me tu, Hafize, pjesme Tvoje,

Dok ih vođa slatko pjeva

$S$ mazginih visokih leđa

Da probudi zvijezde s neba

I razbojnike pokoleba. 
I u hamam i u krčmu kad idem,

Hafiza ću poštovanog da spomenem,

Kada duvak draga mahne,

Amber kosom me zapahne,

Čak pjesnikov šapat ljubavni

Čini i hurije požudnim.

Želite li mu to zavidjeti

Ili možda čak ogaditi,

Znajte samo da pjesnikove riječi

Oko vrata džennetskih

Uvijek tiho kucajući lebde,

Moleći se za život vječni.

[Hejira

North and West and South up-breaking! Thrones are shattering, Empires quaking;

Fly thou to the untroubled East, There the patriarchs' air to taste! What with love and wine and song

Chiser's fount will make thee young

There, 'mid things pure and just and true, The race of man I would pursue

Back to the well-head primitive, Where still from God did they receive Heavenly lore in earthly speech, Nor beat the brain to pass their reach.

Where ancestors were held in awe, Each alien worship banned by law; In nonage-bounds I am gladly caught Broad faith be mine and narrow thought As when the word held sway, and stirred Because it was a spoken word.

Where shepherds haunt would I be seen, And rest me in oases green; When with the caravan I fare, 
Shawl, coffee, musk, my chapman's ware,

No pathway would I leave untraced

To the city from the waste

And up and down the rough rock ways

My comfort, Hafez, be thy lays,

When the guide enchantingly,

From his mule-back seat on high,

Sings, to rouse the stars, or scare

The lurking robber in his lair.

In bath or inn my thought would be,

Holy Hafez, still of thee;

Or when the veil a sweetheart lifts

From amber locks in odorous drifts;

Ay, whispered loves of poet fire

Even the Houris to desire!

Would you envy him for this,

Or bring despite upon his bliss,

Know that words of poets rise

To the gate of Paradise,

Hover round, knock light, implore

Heavenly life for evermore.] $]^{34}$

"Hejira" was Goethe's treatment of the quest (migration!) for the primeval, pure, chaste Nature, for an East where meaning was to be found. Mommsen describes various forms of this quest, claiming that Goethe searched for God in herbis et lapidibus, the plants and stones! Through his writings Goethe emphasised that finding the God of Nature led to finding the divine in man. His line of reasoning had the following trajectory: God-nature-man. The purpose of the quest was discovering the internal, primeval divine knowledge (dei intuitiva), or intuitive science (scientia intuitiva), within oneself. Goethe was a genius led by the principle of amor dei intellectualis in his artistic and intellectual endeavours.

That is why Goethe found the Islamic East marvellous and magical, a place where even the air felt authentic. In the first verse of "Hejira", as we have already mentioned, in 1826, Goethe described flying to the East or, as Mommsen explains, "flying' to the 'untroubled East', to breathe 'the Patriarchs' air"! (nach dem 'neinen Osten' um dort 'Patriarchenluft zu kosten')."35 Goethe found inspiration for his quests in Hafez Shīrāzì and other poets 
of the Islamic East. His enchantment might have been caused by the fact that the poets he got to know through poetry were not poets of despair, but rather poets of joy and brightness. In the words of Mommsen: "For Goethe, as for Hafez, the Earth was not the valley of tears (Für Goethe war wie für Hafis die Erde kein 'Jammertal')."36

Both Mommsen and Neimarlija emphasize the element of 'brightness' in Goethe's art, which the Poet adopted after encountering the work of Hafez: "Typical for both poets is the element of brightness which Goethe refers to when ending his line with 'the bright image of the faith' (heitren Bild des Glaubens)." ${ }^{37}$ The brightness prevented 'disappointment in life (sie bedingt keine Verdüsterung des Lebens), because Hafez and Goethe never renounced this world (sowohl Hafis als Goethe bleiben der Welt zugewandt)! ${ }^{38}$ According to Neimarlija, Goethe's work was imbued with

a nature full of colours, smells and sounds. Indeed, Goethe is the poet of nature, of the bountiful and limitless nature, a nature that never stops transforming into a myriad different shapes... ${ }^{39}$

In short, Goethe recognized "the Islamic affirmation of life embodied in the unforgettable, fantastical world of the '1001 Nights' created in the initial, dazzling period of Islamic history." ${ }^{40}$ (It should be noted that Mommsen also published a separate book in 1960 called Goethe und 1001 Nacht, about Goethe's reception of the Thousand and One Nights.)

The poet Goethe was thrilled to find that the Quran valued this world as God's creation abounding in God's divine signs. This world was no less worthy than the Future one:

at no point does the Quran belittle this world in relation to the next one, calling it a valley of tears contaminated by the original sin (Nirgends aber findet sich im Koran zugunsten des Jenseits eine Abwertung des Dieseits in der Vorstellung eines von der Erbsünde verseuchten Jammertals). ${ }^{41}$

\section{Goethe's Interest in Islam and the Qur'an}

At the age of twenty-three, Goethe slowly began to let his friends in on his fascination with Muhammad and the Quran, an engagement that had started much earlier. Mommsen offers multiple, detailed descriptions of Goethe's interest in various European translations of the Qur'an into Latin, German, and English. He used to compare and evaluate them, write down short comments, and amend and improve the German translation according to his intuition. Goethe seemed to have found these translations 
of the Qur'an "lacking the poetic and the prophetic quality." ${ }^{2}$ We should remember this distinction between poet and prophet.

From his very first encounter with the Qur'anic text Goethe became particularly interested in the "poetic and prophetic issue" (der Problematik des Poeten-und Prophetentums). He believed both kinds of inspiration came from the same source. Furthermore, there was a period in which Goethe learned about the Qur'an from his senior friend Herder, agreeing with Herder's impressive claim that it was impossible to imagine the Quran "as not deriving from the Heavens (er konnte also nicht anders als vom Himmel stammen)."43

As we have already mentioned, Goethe's interest in Latin, German, English and French translations of Islamic texts started early, but the full extent of his fascination with the Qur'an was revealed in July 1772 when Goethe wrote a letter to Herder from Wetzlar, saying:

I want to pray to God the way Moses prays in the Qur'an: "Oh my lord, expand me my breast" (Im Juli 1772 schreibt Goethe von Wetzlar aus an Herder: Ich möchte beten wie Moses im Koran: "Herr mache mir Raum in meiner engen Brust"). ${ }^{44}$

Goethe frequently mentions the 'chest', the 'breast', and the feeling of 'chest expansion' in moments of pleasure or spiritual contentment.

In her research on Goethe's spiritual quests, Mommsen notes that Goethe was averse to any kind of institutionalized religion. Conventional religion and Goethe the Poet seemed to be oceans apart, destined never to meet. A reason for this could be found in Goethe's Protestant upbringing, his anti-church (or anti-clerical) sentiments, as well as his admiration for Martin Luther. Yet although Goethe was born into the Protestant tradition, Protestantism never took firm roots in him, at least not to the extent that would lock and seal Goethe's spirit, making him immune to other spiritual callings. His genius never resided in the narrow, isolated, self-contained regions of the world and the soul.

Reading Goethe's work and Mommsen's book leaves us with the impression that Goethe never allowed any religion, not even Protestantism, to dictate and shape (beyond any debate) the right way to believe in God. He believed the external, institutionalized faith offered to people was not his faith, and he not only rejected the traditional church dogma but also used the same principle when assessing other faiths, religions and worldviews. (We see this in the rare instances of Goethe's displeasure with the Qur'an's 
treatment of poetry and poets. Goethe thus proves that poetry was his primary preoccupation, and that everything else came second).

Goethe's openness to various religious traditions should be interpreted as a result of his poetic and spiritual genius, as well as the fact that his art only strengthened his distrust of 'official religion'. This was the crucial fact of Goethe's life which many enthusiastic Muslim scholars fail to notice or comprehend, with some interpreting it rather preposterously, claiming that Islam had led Goethe to adopt his anti-clerical, anti-church stance! Such a conclusion is simply untenable. Much before delving into Islamic texts (the Qur'an, the hadith, poetry...), Goethe had already form(ulat)ed (albeit only in its outlines), a unique, completely unencumbered faith in God, devoid of strict duties or limitations, which enabled him to fully enjoy his freedom.

It was this attitude, and the effort to reach faith through his genius, that led Goethe to explore Islam, or the aspects of Islam he chose. We could say that Goethe discovered his own Islam through Islamic poets, and not through the Islamic 'ulema', philosophers, and jurists. Goethe's sided with the Islamic poets and appreciated only those 'ulema' who respected poets. He held Shaykh al-Islām Ebussuud Efendi (d. 1574) in high regard because of his fatwa in favour of the metaphors (and the metaphoric reading) of Hafez's Diwan. Through the genius of Islamic poets, Goethe discovered his very own Islam, an Islam revealed to his spirit only, interpreted to him by the poets of the Islamic East with whom he felt a spiritual kinship, regardless of the vast stretches of time and the spatial and cultural distance dividing them.

Goethe developed his views on Islam in the third and fourth decade of his life, namely the seventies and eighties of the eighteenth century. According to Mommsen, "Goethe adopted a firmly positive attitude towards Islam once he found similarities between the main Islamic teachings and his own, personally held views (Sein entschieden positives Verhältnis zum Islam gewann Goethe dadurch, daß ihm gewisse Hauptlehren als übereinstimmend mit seinem eifgenen Glauben und Denken erschienen)." ${ }^{45}$

Mommsen claims that Goethe first form(ulat)ed his own opinions and views, and then picked out the parts of the Qur'an that gave him insight into the main teachings of Islam. Throughout his quest, Goethe remained true to his primary preoccupation, poetry, because his genius was that of a poet and he approached Islam as the Poet who coined the phrase 'world literature' (die Weltliteratur). ${ }^{46}$ Needless to say, Goethe's encounter with chosen Qur'anic parts and chapters was not casual, but impulsive and intense. Mommsen writes that Goethe "essentially approached Muhammad and his 
religion in a much more intimate manner (Vielmehr trat er zu Mohammed und seiner Religion in ein viel persönlicheres Verthältnis)." ${ }^{47}$ He wrote powerful texts honouring Islam and the Qur'an (in dem Islam und Koran auf unvergleichliche Weise geehrt werden). ${ }^{48}$ His intimate and intense exploration of Islamic texts made Goethe realize that "there were other books, besides the Bible, that were holy for many people (das neben der Bibel noch andere Schriften existieren, die grossen Teilen der Menscheit heilig sind)." ${ }^{49}$

According to Mommsen, the spirit of European Enlightenment and the tolerance it preached was not the primary reason why Goethe developed an interest in the Qur'an:

Goethe's early interest in the Qur'an was not prompted by a need to demonstrate religious tolerance that was so often merely a mask for indifference (Keineswegs ging es aber bei Goethes früher Beschäftigung mit dem Koran aussließlich darum, religiöse Toleranz zu demonstrieren, hinter welcher sich oft nichts weiter verbirgt als Indifferenz). ${ }^{50}$

Rather, Goethe the Poet had his own, internal, intimate and, one could say, spiritual and emotional reasons to begin reading the Qur'an. His youthful enchantment with Nature never left him and even grew stronger as he entered old age. It was in the Qur'an that Goethe found confirmation of his teachings and views on Nature.

\section{The Transcendent and the Immanent in Nature: Goethe's Meeting Point with the Qur'an}

Goethe tried to find confirmation for his primordial monotheism primarily in Nature. But Nature was a boundless multitude of things, phenomena, skies, constellations... Faced with the immanence and boundlessness of $\mathrm{Na}$ ture, how was one supposed to reach the Source and the Root, the One who held everything together while remaining unseen (and transcendent)? According to Mommsen, the Qur'an helped Goethe in his quest: “The Qur'an echoed Goethe's belief that man must rise above the diversity of natural phenomena to find the one and only God (Seine Überzeugung, daß der Mensch sich aus der Vielfalt der Naturscheinungen emporheben müsse zur Erkentnis des Einen Gottes, fand er im Koran gleichnishaft vorgebildet)." ${ }^{51}$

We have already mentioned that young Goethe form(ulat)ed the outlines of his faith in God and his Philosophy of Nature. His senses were very much attuned to the wonders of Nature, as evidenced by his later writings in the Theory of Colors. Upon reading Spinoza's Ethics, Goethe found that many of the things in that book concurred with his views on Nature. 
Goethe never renounced the principle Deus sive Natura ('God or Nature'), and this kind of pantheism provided him with many answers to his questions about God.

Although no traditional Islamic school of thought approved of pantheism or attempts to derive pantheism from the Quran, Mommsen notes that Goethe did find confirmation for his views on Nature and his concept of pantheism in the Qur'anic teachings. We will come back to this issue later.

Of course, Goethe the Poet was primarily impressed with the Qur'an ... as a linguistic monument (den Koran als Sprachdenkmal) ${ }^{52}$... describing the Quranic style as...strict, glorious, chilling and at times truly sublime (Der Stil des Koran ist...streng, groß, furchtbar, stellenweis' wahrhaft erhaben). ${ }^{53}$

In the style of the Qur'an Goethe found echoes of the 'style of Nature'. The Poet of Weimar found Nature to be strict, glorious, chilling, sublime... He was glad to see the Qur'an confirm his views.

Mommsen emphasizes that Goethe banished all traces of anthropomorphism from his personal, unique faith in God. Goethe cherished those parts of the Qur'an "citing the regularity and periodicity of natural phenomena (in der Regelmäßigkeit und Periodizität der Naturerscheinungen) as proof of God's glory, instead of offering the believers an antropomorhed vision of God." ${ }^{44}$ Goethe was also enchanted by the vivid imagery of the Qur'an, powerfully portraying the turning from night to day, the changing of the seasons, the movement of winds and clouds. ${ }^{55}$ "One of Goethe's favourite Qur'anic images was the one in which people "grasped how Great and Omnipotent God was through the movement of stars (im Gang der Gestirne sind dem Menschen Zeichen gesetzt für die Größe und Allmacht Gottes)." ${ }^{56}$ In Goethe's literary works the Prophet Muhammad (peace and blessings upon him) was often portrayed as one speaking "under a starlit night sky".

The similarity between Goethe's poetic faith in God and the Islam that Goethe found in the Qur'an was particularly noticeable in the Meccan Surahs. These were his favourite parts. The following similarities between Goethe's personal view on the Oneness of God and the teachings of Islam have been widely noted:

- the teaching on the oneness of God (die Lehre von der Einheit Gottes);

- the belief that God reveals Himself through nature (die Überzeugung, daß Gott sich in der Natur offenbare); 
- the belief that people learn about the manifestations of God through the Prophets (und diese Offenbarung durch verschiedene Abgesandte der Menschheit übermittle);

- renunciation of "miracles" (das Abweisen von 'Wundern'); and

- the belief that faith must be proved through good deeds (und die Auffassung, daß der Glaube sich in wohltätigem Wirken erweisen müsse). ${ }^{57}$

At one point, all of this prompted Goethe to write that he did not reject the suspicion that he himself was a Muslim ("lehne den Verdacht nicht ab, dass er selbst ein Muselmann sei”). ${ }^{58}$ Interestingly, in one period of his life Goethe used the word Islam as a maxim and (a kind of) principle in letters to friends. (Mommsen also mentions this several times). Goethe's friends had grown accustomed to him using Islamic terms and words, even the word Islam, in their encounters and correspondence.

Goethe had a reputation, especially among his friends, as the Poet who celebrated Nature, viewing it as God's master creation, never to be fully comprehended. He was particularly thrilled to learn that natural phenomena were called $\bar{a} y \bar{a} t$ - signs of God - in the Qur'an, and noted with joy "that the Qur'an taught people how to consider Nature with all its phenomena (Der Koran lehrt, wie der Mensch die Natur in allen ihren Phänomenen betrachten soll) (and interpret them) as evidence of God's laws (als Beweise göttlicher Gesetze)." 59

Goethe was enchanted by the freshness, the power, the strength, the vigor, and the flourishing of nature. West-Eastern Diwan, Faust, and many other poetic works of Goethe read as hymns to Nature, hymns written in the midst of Nature's kingdom. Putting Nature on a pedestal in his poetic works was Goethe's way of saying that "by acquainting himself with the abundance, the diversity and the laws of Nature, man came closer to knowing the Reign of God: the One God behind the multiplicity of phenomena (wird der Mensch auf das göttliche Walten hingewiesen: auf den Einen Gott der Vielheit der Erscheinungen)." ${ }^{60}$

Goethe was happy to find himself at the intersection between the Qur'anic discourse on Nature and Spinoza's pantheism because he came to believe very early on that Nature represented God's doing; that it was, in fact, God's never-ending revelation. Meaning to say, "Goethe found in it the confirmation that the Divine manifested itself in Nature (daß das Göttliche sich in der Natur offenbare)." ${ }^{\prime 1}$ 
We should not lose sight of the fact that Goethe promoted these views in his poetry. He wanted to (and partly succeeded in) poetically inhabit (or make his home) those parts of the Qur'an that corresponded to his hymns about Nature. Thus Goethe found himself on the path of Sufism, inspired by the Sufi and Islamic mystics to find the One and Only God in everything: "to find the Oneness and Divinity in everything corresponded to the Poet's own religious sentiments (In allem das Eine zu erblicken, das Göttliche, entsprach des Dichters eigener Religiosität)." ${ }^{2}$ Goethe was staunchly opposed to the scholastic principle of dualism and its teachings about "the holy love of God" versus "the unholy love of Nature." The latter phrase (Unheilige Naturliebe) was extremely insulting to Goethe's "faith" in Nature. ${ }^{63}$

Goethe's writings about Nature were met with joy by many Muslim authors. Neimarlija noticed nature was a constant presence in Goethe's work: "The grand, beautiful nature that was not frightening or mysterious, or impure, exempt from God's grace, was the main topic and the main material of Goethe's poetic expression." ${ }^{4}$ For these reasons Goethe adopted a 'wholly Islamic view' on the issue of abstinence:

Goethe's line of reasoning was this: abstinence-yes, but only so one could experience the wonders of the afterlife in this life; asceticism in the sense of repudiating this world by renouncing the flesh - no. ${ }^{65}$

\section{Goethe's Acceptance of the Islamic Concepts of Destiny and Doing Good Deeds}

Mommsen devotes many pages to describing Goethe's belief that Islam "required yielding to the undecipherable will of God" (Ergeben in den unergründlichen Willen Gottes). ${ }^{66}$ Goethe's famous verse (translated by Edward Dowden)-

Närisch, daß jeder in seinem Falle

Seine besondere Meinung preist!

Wenn Islam Gott ergeben heißt,

In Islam leben und sterben wir alle.

[The folly! Every man in turn

Would still his own particular notions magnify!

If Islam mean submission to God's will,

May we all live in Islam and all die.] 
-would suggest Goethe understood and defined Islam as an all-encompassing, but very flexible, omnipresent state of poetic joy about the existence of God. In short, this was Goethe's Islam, an Islam freed from the interpretations of Sharía jurists, the caliphates' Shaykh al-Islāms and their fatwas, etc. Goethe was not interested in such theological, legal and moral systems, nor did he feel the need to delve into an Islam of that kind. There has been no evidence to suggest (and had there been, Mommsen would have found it) that Goethe perceived Islam from the point of view of its creed/sharia/moral system. The Poet's Islam was supra-religious and broad, an Islam in which the various Islamic historical systems were not yet in confrontation with any religion or any side of the world, an Islam that was not in opposition to art and poetry. As mentioned before, whenever Goethe perceived the Qur'an and the Prophet to be neglectful of poetry, he never failed to react, always siding with poetry (and therefore himself).

As Goethe saw it, the (Islamic) principle of yielding to God's will also led to a very difficult decision of accepting destiny as predetermined by God. The future appeared as a certainty, a destiny in which one should believe. Yet Goethe emphasized doing good deeds ( $a l$ șālihâat) as one of the cornerstones of the Qur'an. Although a Protestant by birth, Goethe always publicly criticised the Lutheran notion that, as Mommsen put it, "man must strive only to recognise the goodness of Jesus and (thereby) earn his grace (daß der Mensch einzig und allein trachten müsse, die Verdienste Christi zu erkennen und sich seiner Gnaden teilhaftig zu machen)." As for the principle of doing good deeds (al-șālihāt) Goethe was much closer to the Catholic teaching (Lehre von den guten Werken); he believed that "through good deeds, forbearance and his bequests man can absolve himself of sin and enjoy the grace of God (daß nämlich der Mensch durch Gutestun, Vermähtnisse und milde Stiftungen eine Sünde abverdienen und sich überhaupt in der Gnade Gottes dadurch heben könne)." ${ }^{\prime 7}$

The similarities between Goethe's view on good deeds and the Qur'anic imperative of doing good as a way of outwardly confirming one's faith can be found in numerous sources. According to a letter written to Eckermann on June 20,1872, Goethe believed that "upholding the right kind of faith" would itself lead people to "do good deeds". ${ }^{68}$ But why did Goethe, from his position of a Poet, subtly bring into connection the doing of good deeds with destiny?

Mommsen notes that Goethe recognized in Islam "belief in the immutability of God's providence as the cornerstone of faith (die Unabänder- 
lichkeit der göttlichen Vorsehung)." ${ }^{69}$ Two questions should be posed here: Did Goethe the Poet mean to prove by this that Spinoza's principle God or Nature could (and should) be justified by the Islamic principle of God or Destiny? Further, could the principle 'God or Nature' be introduced into Islam under the guise of the principle 'God or Destiny'? In any case, by insisting on doing good deeds, Goethe wanted to show that those who did good had a say in their destiny, they participated together with God in its creation.

Just as the Islamic poets wrote about beautiful and mighty nature as a stage for an infinite number of ever-evolving forms, so too did they longingly sing about God, the Eternal, Ever-Wakeful God, as the almighty conferrer of destiny that man could influence and change by doing good deeds. The Islamic poets' belief in destiny informed Goethe of the ways in which it could be changed; or, to be more precise, man could change destiny (only!) by believing in it!

This was another point of contention between Goethe and the Enlightenment movement, ${ }^{70}$ since the latter viewed Nature as a machine that functioned without fail. Goethe was confronted with determinism and irreversibility in Nature, as well as the belief that irreversibility was intrinsic to all God's actions and doings. Determining whether God's grace was the one attribute of God which could reverse Nature's irreversibility and change Destiny was a difficult task. However, we should keep in mind the following: destiny changed by God did not become something else; it remained destiny, because it came from God.

For Goethe, God was not an omnipresent, impenetrable granite fortress, encompassing all creatures and not allowing any unforeseen steps. Once again, Goethe the Poet found himself on the same path as the Islam he came to know.

\section{Goethe and the Primacy of Poetry}

Mommsen excels in describing one aspect of Goethe's spiritual life: the Poet's task, or his mission. Like Mommsen, Bajraktarević comments on Goethe's unorthodox views, for the latter

openly admitted being opposed to the Quranic dualistic views on Heaven and Hell as well as the Quranic ethics expressed through commandments and prohibitions, but emphasised that he still respected the Quranic text. ${ }^{71}$ 
These views were a result of his commitment to poetry, his need to create a rivalry (der Wettstreit) between prophecy and poetry.

We should note that Goethe did not approach all great historical figures from Islam in the same way. He considered poets to be more important than theologians and philosophers. Goethe criticised the over-education (Überbildung) of "Ṭus", ${ }^{72}$ this being a metaphor for theology and the kalām of al-Ghazali (d. 1111). The poetry of Hafez Shīrāzī and Islam took primacy.

In her discussion of the relationship between texts revealed by God and poetry, Mommsen might have overemphasized the alleged Islamic conflict between theology and poetry in order to create an equivalent to the medieval conflict between theology and philosophy in the West. This aspect of Mommsen's work requires special attention. At one point she describes the recent ceremonies held in Arab capitals commemorating the $1000^{\text {th }}$ anniversary of the death of the poet al-Mutanabbì (d. 955). If there was in fact such a conflict in Islam between prophecy and poetry, why would the capital cities of the Arab world commemorate the death of a poet in such obvious fashion?

But back to Goethe, whose quest for great people in other religions, cultures and civilizations became so important to the Muslims. Goethe always claimed that "History knew of great religious teachers outside the Christian sphere (daß die Geschichte auch außerhalb des christilichen Bereichs große Religionslehrer kennt)." ${ }^{\prime 3}$ His relationship to God's prophet $\mathrm{Mu}-$ hammad took up an entire, special chapter in his life. For example, when translating Voltaire's drama Mahomet (Muhammad) into German, he did his best not to demean the Islamic Prophet. He modified some of Voltaire's views, editorializing and adding new parts to the extent that, according to Schimmel, Goethe's German translation (and adaptation) of this work represented a kind of anti-drama to Voltaire's Mahomet. ${ }^{74}$ We have also seen how impressed Goethe was with the style of the Qur'an, which led him to spend decades exploring the "similarities between the mission of the Prophet and the mission of the Poet (Der Gedanke der Verwandtschaft zwischen der Sendung eines Propheten und der eines Poeten war zweifellos von Goethe mit Herder erörtert worden...)." ${ }^{\prime 5}$ Once again we see Goethe's poetic genius shine through. Goethe the poet did not just "identify" to a certain extent with the Prophet; ${ }^{76}$ he also may have expected that, as the most celebrated writer and poet of Europe, he too could expect a Poetic Revelation from God. 
In his Song for Muhammad (Mahomets Gesang), Goethe expressed his admiration and enchantment, opening up his young heart to the influence of the Prophet. Goethe wrote the poem in the spring of 1773, having (per Mommsen) read all available sources on Muhammad. In Song for $\mathrm{Mu}$ hammad Goethe develops the metaphor of a river flowing towards God. ${ }^{77}$ Schimmel comments that Muhammad Iqbal was so thrilled by Goethe that he decided to translate Mahomets Gesang into Persian, noting even that

the translation was a free one, and no poem could come close to expressing the dynamic power of the Prophet more beautifully than Goethe's words. However, neither Iqbal nor Goethe could predict a rather interesting twist, namely the fact that the metaphor of the Prophet as a river had already been used in the $10^{\text {th }}$ century by Shia theologian Kulini. ${ }^{78}$ Once again, Goethe's intuition led him to write something that Muslims found agreeable. ${ }^{79}$

According to Mommsen, Goethe spent a great deal of time with the pietists gathered around his friend from Frankfurt, Susanne von Klettenberg, while he worked on the Muhammad Tragedy (Der Mahomet-Tragödie). There were many other circles, elite and private, even esoteric ones, in which Goethe held his famous speeches about Islam and its Prophet. As we have learned, Goethe loved to portray the Prophet as speaking alone, under a starry sky (the glorious verses of the Hymn revolved around this image). In short, with the positive resolution of Muhammad Goethe dissociated himself from the negative portrayal of Muhammad in Europe. ${ }^{80}$

But what was Goethe's intention? Was there a secret, lofty aim behind his long-time admiration and glorification of Muhammad (upon him blessings and peace)? According to Mommsen, "Goethe saw in prophet Muhammad a person who did something very useful by revealing the faith in one God." Moreover, we could understand Goethe himself to see "his own mission as a poet from a religious perspective." The Poet Goethe "became an inspiring model and an example of a higher spiritual life." ${ }^{\prime 1}$ As a poet, Goethe wished to "work for other people as for his brothers, enchanting them and leading them to a higher life (für die Menschen als für seine Brüder zu wirken, sie mitzureißen, mit sich hinanzuziehen $z$ u einem höheren Leben)." 82

Goethe was right (and true to himself) when he based his mission of renewal in poetry. He realised that his work could not "solely" consist of poetry (sein Wirken durfte einzig und allein im dichterischen Schaffen bestehen). ${ }^{83}$ And so he sought to "bring his contemporaries closer to God-Na- 
ture", 84 and laid out in his poetry a personal view of God, as seen through the eyes of the spirit and the heart, as well as the mind and the intuition of a genius. As mentioned before, through his work Goethe became a distinct proponent of a subtle faith in God. He reached for those Islamic teachings that affirmed this faith. But did this express his desire to become something other than a poet?

The question is important, especially for Muslim readers of Goethe's work, for whom the role of the prophet trumps that of a poet. Muhammad was the last prophet of God and the cycle of prophets ended with him. In contrast, Goethe's poetry did not pay much heed to sealed doors; the same could be read in Mommsen's book, when she describes young Goethe as a daring man who made important decisions: being thrilled with pantheism and Nature, he decided "to opt for the Poet's, not the Prophet's calling" (die Poeten- und nicht die Propheten-Laufbahn einzuschlagen). ${ }^{85}$ Goethe acted through his poetry; he loved to observe himself as he acted and wrote (Wenn ich handle, wenn ich dichte...). ${ }^{86}$ Through poetry as the highest form of action, Goethe revealed the Divine in nature and man and this became, as Mommsen observed, the central topic of his poetry (Wie wir wissen, war Offenbarung des Göttlichen in der Natur wie im Menschen das zentrale Thema von Goethes dichterischem Werk). ${ }^{87}$ The Islam Goethe discovered on the way represented a tool, while poetry was the final aim.

In conclusion we should note that Goethe's treatment of Islamic topics was a true example of the fitra (primordial human nature) described by the Islamic mystics. Each one of us carries this primordial nature, regardless of the faith we end up accepting or rejecting. Goethe's descriptions of Ur-phenomena (Urphenomenen) were very much in line with the descriptions of fitra. Goethe's genius recognised the eternal aspects and the eternal nature of Islam. The impermanent aspects were less appealing to Goethe. It was an "Islam as viewed from Goethe's pedestal," as Hilmo Neimarlija rightly put it. ${ }^{88}$ 


\section{Endnotes}

1. Emil M. Sioran, Silogizmi gorčine (Belgrade, 1998), 17 [English translation by Richard Howard].

2. Hilmo Neimarlija, "Vrijeme filozofije povijesti", in Filozofija povijesti, ed. Hilmo Neimarlija (Sarajevo: Fakultet islamskih nauka, 2006), 17.

3. See Enes Karić, "Annemarie Schimmel, diva orijentalnih i islamskih znanosti u Evropi," afterword in Annemarie Schimmel, Odgonetanje Božijih znakova (fenomenološki pristup islamu) (Sarajevo: El-Kalem, 2001), 467-481.

4. Katharina Mommsen, Goethe und der Islam (Frankfurt: Insel Verlag, 2001).

5. Nerkez Smailagić translated almost an entire library of books from German, including Oswald Spengler's Der Untergang des Abendlandes (The Decline of the West).

6. Many have written about Goethe and the Bosnian Muslim traditional ballad Hasanaginica. The best source is Alija Isaković's Hasanaginica, 1774-1974 (Sarajevo: Svjetlost, 1975). A part of the book has been published separately under the title Bibliografija radova o 'Hasanaginici', 1774-1974, by Mustafa Ceman and Alija Isaković. We also recommend the following works on Hasanaginica: Smail Balić, "Goethes 'Klagegessang Von Den Edlen Frauen Asan Agas', Eine bosnische Volksballade erobert die Welt," Österreichische Osthefte (1978): 244-253; Jagoda Truhelka, Kamila Lucerna, Južnoslovenska balada o Hasanaginici, njezin prijevod od Goethea, a separate publication from 'Školski Vjesnik' (Sarajevo: Zemaljska štamparija, 1906); see also "Hasanaginica," Takvim (1395/1975): 179-191 and Alija Isaković, "Hasanaginica," Takvim (1396/1976): 156.

7. Cf. Katharina Mommsen, "Geteov odnos prema islamu," Gazette of VIS (Glasnik Vrhovnog islamskog starješinstva) no. 7-8 (July/August 1968): 324333.

8. Cf. Takvim (1391-1392/1972): 161-173. Although it says "translated from English", the name of the translator is not given.

9. See Hilmo Neimarlija, “Dug Geteu," Islamska misao 5, no. 51 (March 1983): 40-47.

10. Fehim Bajraktarevićs study was originally published in Godišnjica Nikole Čupića (Belgrade, 1939). It was also released as a separate publication.

11. Ibid., 36.

12. Neimarlija, "Dug Geteu."

13. Ibid., 40.

14. Cf. Akbar Moghaddas, "Goethe - musliman?" Glasnik Rijaseta Islamske zajednice, no. 9-10 (September-October 1999), 991 onwards. Translated by Salim A. Hadžić (Gazette of the Riyasat of the Islamic Community, no. 1-2 [2000]: 78), who explains that the essay was written by Akbar Moghaddas, 
not Katharina Mommsen, as was mistakenly claimed in Gazette of the Riyasat of the Islamic Community, no. 9-10 (1999).

15. See Annemarie Schimmel, "Gete i islam," trans. Salim A. Hadžić., Gazette of the Riyasat of the Islamic Community, nos. 1-2; 3-4; 5-6 (2000).

16. The note accompanying the first part informs the readers that the article Goethe und der Islam was written by Annemarie Schimmel in German, and that it was originally published in Hamburg, in Al-Fadschr 16, no. 95 (1999).

17. Cf. note by Hadžić in Gazette of the Riyasat of the Islamic Community, no. 1-2 (2000): 69.

18. Cf. Katharina Mommsen, Goethe und die arabische Welt (Frankfurt am Main: Insel, 1988).

19. Cf. G.W. Wickens, "Hafiz", The Encyclopaedia of Islam (Leiden: E.J. Brill, 1986), 3:55.

20. E.g., in the circle of Abu Bakr Rieger and his friends formed around the German newspaper Islamische Zeitung, Goethe is treated as a Muslim. They even issued a fatwa regarding Goethe's Islam, as discussed by Mommsen.

21. For more on Goethe's relationship with the cross, see the study by Salim A. Hadžić, "Pjesma Hidžra od Getea," Gazette of the Riyasat of the Islamic Community BiH, no. 7-8 (2007): 623 onwards.

22. Mommsen, Goethe und der Islam, 22.

23. Ibid., 21.

24. Ibid., 22.

25. Ibid.

26. Ibid., 22-23.

27. Ibid., 23.

28. Ibid., 24.

29. Hilmo Neimarlija, "Vrijeme filozofije povijesti," in Filozofija povijesti, ed. Neimarlija (Sarajevo: Fakultet islamskih nauka, 2006), 17.

30. Karl Lewith, "Goethe i Hegel," in Od Hegela do Nietzschea (Sarajevo: Logos, 1987), 19.

31. Schimmel, "Gete i islam," Gazette of the Riyasat of the Islamic Community, no. 1-2 (2000): 74; emphasis added.

32. Edward Said, Orijentalizam, translated by Biljana Romić (Zagreb, 1999), 32. The Bosnian translation of Said's Orientalism was done by academic Rešid Hafizović (Sarajevo: Svjetlost, 1999).

33. Cf. Salim A. Hadžić, "Pjesma Hidžra od Getea," Gazette of the Riyasat of the Islamic Community BiH, no. 7-8 (2007), 623 onwards.

34. Translated by Edward Dowden.

35. Mommsen, Goethe und der Islam, 140-141. In Adonis' Sufism and Surrealism (London: Saqi Books, 2005), 197, this verse was translated as: Save yourself! Go to the pure East / and breath into breath of your fathers!

36. Mommsen, Goethe und der Islam, 140. 
37. Ibid.

38. Ibid.

39. Neimarlija, "Dug Geteu," 44.

40. Ibid.

41. Mommsen, Goethe und der Islam, 67.

42. Ibid., 32.

43. Herder, Plastik, in Mommsen, Goethe und der Islam, 44.

44. Mommsen, Goethe und der Islam, 26.

45. Ibid., 20.

46. For more information on the phrase 'world literature', see entries in Vladimir Biti, Pojmovnik suvremene književne teorije (Zagreb: Matica Hrvatska, 1997).

47. Mommsen, Goethe und der Islam, 20.

48. Ibid.

49. Ibid., 21.

50. Ibid.

51. Ibid., 59 .

52. Ibid., 24.

53. Ibid., 25.

54. Ibid., 37.

55. Ibid.

56. Ibid.

57. Ibid., 25.

58. Ibid., 227.

59. Ibid., 38.

60. Ibid.

61. Ibid.

62. Ibid.

63. Ibid., 54.

64. Neimarlija, "Dug Geteu," 44.

65. Mommsen, Goethe und der Islam, 210.

66. Ibid., 25.

67. Ibid., 37.

68. Ibid.

69. Ibid.

70. For more on philosophical aspects of German Enlightenment, see Lewith, Goethe i Hegel."

71. Bajraktarević, "Utjecaj istoka na Getea," 35.

72. Cf. Mommsen, Goethe und der Islam, 318.

73. Ibid., 38.

74. Schimmel, Gete i islam, 76.

75. Mommsen, Goethe und der Islam, 43.

76. Ibid., 45 . 
77. Ibid., 54.

78. Sometimes in Bosnian literature the name is cited as Kulajni.

79. Schimmel, Gete i islam, 236 and 237.

80. Mommsen, Goethe und der Islam, 69.

81. Ibid., 57.

82. Ibid.

83. Ibid., 76 .

84. Ibid., 71.

85. Ibid., 79.

86. Ibid., 157.

87. Ibid., 195.

88. Neimarlija, "Dug Geteu," 43. 